\title{
Strength and Durability Characteristics of Cement-lime Mortars with Fly Ash and Slag as Aggregate Substitutes
}

\author{
Paweł Kończalski ${ }^{1}$, Jacek Katzer ${ }^{1 *}$ \\ ${ }^{1}$ Faculty of Geoengineering, University of Warmia and Mazury in Olsztyn, ul. Prawocheńskiego 15, 10-720 Olsztyn, Poland \\ * Corresponding author, e-mail: jacek.katzer@uwm.edu.pl
}

Received: 06 March 2021, Accepted: 29 March 2021, Published online: 13 April 2021

\begin{abstract}
The global consumption of sand by the concrete industry has increased significantly over the years. Natural sand has become a desired commodity in numerous regions of the world. To protect both the existing resources of natural sand and utilize waste materials, drastic actions are urgently needed. The production of cement mortars, which are solely based on fine aggregate, is responsible for the large consumption of natural sand. In the described research program, we proposed to substitute $50 \%$ of the natural sand in mortars with fly ash and slag. The strength properties and durability characteristics of the new mortars were tested. It was proved that mortars with fly ash and slag can be used for specific applications in civil engineering. Areas for future research associated with the mortars in question were also pointed out.
\end{abstract}

Keywords

mortar, fly ash, slag, lime, cement

\section{Introduction}

Since the time of the Roman Empire, cement and lime mortars have played a key role in civil engineering. Originally developed for the erection of brick walls, over the centuries, they have also gained the role of being an essential material for finishing works, rendering, floor preparation, etc. When modern concrete was born at the beginning of the $19^{\text {th }}$ century, it was differentiated from mortars in that, apart from sand, it also used coarse aggregate. Later on, concretes were based on other mixes besides those employed in mortars, which were created by mixing a binder (cement, lime, or both) in basic mass proportions with sand and adding water to achieve the desired workability. At the end of $20^{\text {th }}$ century, this traditional division between concretes and mortars started to be blurred. New types of concretes emerged in the second half of the $20^{\text {th }}$ century, such as steel fiber-reinforced concrete (SFRC) [1, 2], self-compacting concrete (SCC) [3, 4], high- and ultra-high-performance concrete (UHPC) [5, 6], which are based on much higher volumes of fine aggregates than ordinary concrete. In some cases, these new concretes consist of only fine aggregates (up to $2 \mathrm{~mm}$ or $4 \mathrm{~mm}$ ). At the same time, modern mortars became very sophisticated. They are designed in a very similar way to concrete mixes and modified by admixtures and additives. Brand new fine aggregate challenges are associated with the 3D-printing of concrete, which is basically a very special type of mortar $[7,8]$. One may state that in the year 2021, it will no longer be viable to differentiate mortars from concretes, especially using the criterion of the maximum diameter of aggregate used.

The heavy global consumption of concrete, which surpasses $1 \mathrm{~m}^{3}$ per person per year $[9,10]$, together with the higher amount of sand needed for the production of an average cubic meter of concrete than that 50 years ago, has significantly impacted the natural resources of fine aggregates. In some areas of the world, ordinary sand is gradually becoming the most important, but least appreciated, commodity [11]. Mining sand in aggregate pits or through river dredging is also quite destructive for the environment. This situation is driving the need to find alternative aggregates for concrete and mortar production. Multiple research teams have addressed this issue by studying possible applications of waste materials, such as crushed waste concrete [12, 13], crushed glass [14, 15], crushed waste red [16-18] or white ceramics [19], manufactured sand from crusher dust [20], marble powder [21], etc. In the authors' opinion, the sources of materials for sand 
substitution should be located as close to building sites as possible [22]. Therefore, numerous solutions should be developed, and from this palette, local contractors or ready mix producers should be able to choose the right one for them. Keeping the above facts in mind, the research team focused on using slag and fly ash for the substitution of ordinary sand. Both of the waste materials are commonly available in industrialized countries and are partially used for cement production [23] and for the creation of ordinary concrete $[24,25]$.

A lot of studies have reported research programs dedicated to employing fly ash. Fly ash has mainly been used as a cement replacement (up to $50 \%$ of the cement mass) [2628]. This approach has two significant limitations. The first one is associated with the very high quality of used fly ash (which is usually taken directly from electro-filters). The second limitation is connected with the standard requirements (PN-EN 206+A1:2016) [29]. According to the standard, the amount of fly ash in mortars and concretes may reach $30 \%$ of the cement mass. This means that the utilization of fly ash in mortar or concrete production is practically limited to $120 \mathrm{~kg} / \mathrm{m}^{3}$ [30]. Only a partial substitution of sand with fly ash would enable the use of fly ash of different qualities (including old waste fly ash) and significantly increase its volume in cement composites. A similar situation applies in the case of slag. Only recently, apart from using a high-quality slag and treating it for cement replacement, some research teams have focused on using it as a partial replacement for sand [31]. This approach was successfully tested in the case of different types of concretes, including self-compacting concretes [32]. It was noted that concretes with sand partially replaced by slag are characterized by a longer curing time in comparison to concretes without slag. Nevertheless, the key issue that should be addressed is the durability of such cement composites [33, 34].

In the current study, the possible application of slag and fly ash in their almost raw form is examined. The research team was convinced that only a significant replacement of natural sand by waste materials will influence the sand consumption in a noticeable way. Therefore, it was decided to base the research program on a $50 \%$ replacement of natural sand. Moreover, since brickwork structures are popular in Europe (where buildings are exposed to water penetration and freeze-thaw cycles), apart from the mechanical characteristics, the durability properties of the achieved mortars were of key interest. The mortars in question were prepared without any admixtures.
They were characterized by the same consistency achieved only by adding cement paste. The strength and durability characteristics of the tested mortars were compared with the EN requirements for ordinary mortars.

\section{Used materials}

The prepared mortars were based on the composition of standardized mortar, which is commonly used for tests of the strength properties of cements [35] and other binders. During the research program, two binders - CEM I 42.5 R and quicklime - were used. Natural sand of a post-glacial origin was used as the aggregate. Key granulometric properties of the used sand are summarized in Table 1. The apparent density and loose bulk density of the used sand were equal to $2.56 \mathrm{~g} / \mathrm{cm}^{3}$ and $1.61 \mathrm{~g} / \mathrm{cm}^{3}$, respectively. The mineral composition of the sand was as follows: quartz, chalcedony, and opal - $81.5 \%$; igneous and metamorphic rocks $-12 \%$; and sediment rocks $-5.3 \%$ [36].

Slag and fly ash were used as partial substitutes for natural sand. Raw slag, characterized by an apparent density of $2.0 \mathrm{~g} / \mathrm{cm}^{3}$ and $\mathrm{pH}<12.5$, was sourced from a local heating plant (Golub-Dobrzyń, Poland). It was grounded with the help of the Los Angeles abrasion machine [38] and sieved, before being used as a partial substitute for natural sand. A sieve of a $2 \mathrm{~mm}$ square aperture was utilized to remove coarse slag particles. Fly ash (class F), characterized by a loss of calcination equal to $4 \%$ and pozzolanicity of $84 \%$, was obtained from a cement plant. The fly ash was characterized by a loss of ignition of $15 \%$ (tested according to PN-EN 196-2:2013-11 [39]), and $20 \%$ of the particles were characterized by a diameter of up to $0.045 \mathrm{~mm}$. There was no unbound calcium. It was also used as a partial substitute for natural sand. The oxide composition of the used fly ash is presented in Table 2 .

The densities of the fly ash and slag are presented in Table 3. All of the aggregates were oven dried $\left(+105^{\circ} \mathrm{C}\right)$, before being used for the creation of mortars. Ordinary tap water was the last ingredient of the mortars in question.

\section{Design of experiment and testing methods}

The design of experiment covered the testing of four mortars. One mortar was a reference mortar. It was a standard mortar (SM), which is usually utilized for testing the

Table 1 Key granulometric properties of the used natural sand

\begin{tabular}{lccc}
\hline Median diameter [37] & \multicolumn{3}{c}{ Fineness modulus by } \\
\hline$[\mathrm{mm}]$ & Kuczyński & Hummel & Abrams \\
0.531 & 3.573 & 75.182 & 2.499 \\
\hline
\end{tabular}


mechanical characteristics of cements and similar binders. This mortar was successfully utilized by the research team for multiple non-conventional approaches, including cement composites reinforced by spatial 3-D printed elements [40]. The SM is characterized by a water-cement ratio of 0.5 , and no admixtures were used for its creation. The other three mortars tested during the research program were modified by a substitution of $50 \%$ of natural sand with equal volumes of fly ash and slag. In addition to this, $15 \%$ of the cement was substituted with quicklime to maintain a good workability of the modified mortars (MM). The modified mortars were differentiated by a water-binder ratio ranging from 0.4 to 0.5 . The initial composition of all four mortars is presented in Table 4.

The first stage of the research program covered the testing properties of fresh mortars (consistency and density) and the adjustment of the mortar recipes. The mortars presented in Table 4 were cast, and their consistency was tested using the flow table method, PN-EN 1015-3 [41]. The consistency of the modified mortars was significantly stiffer in comparison to that of SM. The composition of the modified mortars was changed using an experimental iteration method. The cement-lime paste was added to the modified

Table 2 Oxide composition of the used fly ash

\begin{tabular}{lc}
\hline Oxide & Content [\%] \\
\hline $\mathrm{SiO}_{2}$ & 48.0 \\
$\mathrm{Al}_{2} \mathrm{O}_{3}$ & 28.0 \\
$\mathrm{Fe}_{2} \mathrm{O}_{3}$ & 8.0 \\
$\mathrm{FeO}$ & 6.3 \\
$\mathrm{CaO}$ & 3.8 \\
$\mathrm{MgO}$ & 2.7 \\
$\mathrm{Na}_{2} \mathrm{O}$ & 0.8 \\
$\mathrm{~K}_{2} \mathrm{O}$ & 0.4 \\
Other & 2.0 \\
\hline
\end{tabular}

Table 3 Density of the materials used as aggregates [g/cm3]

\begin{tabular}{|c|c|c|c|c|}
\hline & Natural sand & & Fly ash & Slag \\
\hline Apparent & Loose bulk & & Compacted bulk & \\
\hline 2.56 & 1.61 & 1.81 & 1.04 & 0.77 \\
\hline
\end{tabular}

\begin{tabular}{lcccc}
\multicolumn{5}{c}{ Table 4 Initial composition of mortars [g] } \\
\hline & SM $(0.5)$ & MM 0.4 & MM 0.5 & MM 0.6 \\
\hline Cement & 450 & 382 & 382 & 382 \\
Lime & - & 68 & 68 & 68 \\
Water & 225 & 180 & 225 & 270 \\
Sand & 1350 & 675 & 675 & 675 \\
Fly ash & - & 193 & 193 & 193 \\
Slag & - & 143 & 143 & 143 \\
\hline
\end{tabular}

mortars, until their consistency reached values similar to the consistency of SM (max. $10 \mathrm{~mm}$ difference). The same consistency of all tested mortars formed a reference point for the analysis of the achieved results. The adjusted composition of the modified mortars, with their consistency values and density of fresh mixes (PN-EN 1015-6:2000 [42]), are given in Table 5.

The following stages of the research program were solely focused on properties of mortars presented in Table 5. The recipes presented in Table 5 were used to cast 45 prism specimens $(40 \mathrm{~mm} \times 40 \mathrm{~mm} \times 160 \mathrm{~mm})$ from each type of mortar. The curing process was divided into three phases. Phase 1 covered the first 48 hours after casting the specimens. During this period, the specimens were kept in steel molds covered by glass sheets. Phase 2 lasted 5 days and started after the demolding. The specimens were kept at a temperature of $+20^{\circ} \mathrm{C} \pm 0.5^{\circ} \mathrm{C}$ and relative humidity of $95 \% \pm 5 \%$. After 7 days of curing, Phase 3 of the curing process was initiated. The relative humidity was lowered to $65 \% \pm 5 \%$. The specimens were kept in these conditions until testing.

The tests conducted on the hardened mortars covered the mass of specimens, flexural and compressive strength, absorptivity, capillary action, and loss of mass after the freeze-thaw cycles, which were conducted using tap water and a $3 \% \mathrm{NaCl}$ solution. All tests were conducted using 6 specimens. Only compressive strength tests were conducted using 12 specimens. The flexural and compressive strength were tested after 2, 7, 14, 28, and 56 days of curing. The strength tests were conducted according to PN-EN 196-1:2016-07 [43]. The absorptivity and capillary action were tested after 28 days of curing. The loss of mass after the freeze-thaw cycles was conducted for 50 cycles. One cycle consisted of exposing fully saturated specimens to freezing for $4 \mathrm{~h}$ at a temperature of $-20^{\circ} \mathrm{C} \pm 1^{\circ} \mathrm{C}$

Table 5 Adjusted composition of mortars

\begin{tabular}{|c|c|c|c|c|}
\hline Ingredient & SM (0.5) & MM 0.4 & MM 0.5 & MM 0.6 \\
\hline \multicolumn{5}{|c|}{$[\mathrm{g}]$} \\
\hline Cement & 450 & 726.4 & 497 & 440 \\
\hline Sand & 1350 & 675 & 675 & 675 \\
\hline Water & 225 & 342 & 292.5 & 303.7 \\
\hline Fly ash & - & 193 & 193 & 193 \\
\hline Slag & - & 143 & 143 & 143 \\
\hline Lime & - & 128.6 & 88 & 79 \\
\hline \multicolumn{5}{|c|}{ Properties of fresh mortar mix } \\
\hline Consistency [mm] & 112 & 114 & 116 & 121 \\
\hline Density $\left[\mathrm{g} / \mathrm{cm}^{3}\right]$ & 1.822 & 2.081 & 2.027 & 1.987 \\
\hline
\end{tabular}


and then to thawing for $4 \mathrm{~h}$ at a temperature of $+20^{\circ} \mathrm{C} \pm 1^{\circ} \mathrm{C}$. The freeze-thaw cycles were executed in a fully automated chamber. The properties of the specimens exposed to the freeze-thaw cycles were checked at the beginning of the test (after 28 days of curing) and after 12, 26, 38, and 50 cycles. The water absorption coefficient due to the capillary action of hardened mortar was determined according to PN-EN 1015-18 [44]. The test was conducted using oven dry specimens. Longer edges of prisms were waterproofed by wrapping them with insulation tapes. The end face of each specimen was immersed in water at a depth of $5 \mathrm{~mm}$ to $10 \mathrm{~mm}$ for $10 \mathrm{~min}$. and $90 \mathrm{~min}$. The specimens were weighed before and after the test to check for any increase in mass. Capillarity is characterized by the water absorption coefficient, which can be calculated according to the following Eq. (1):

$C=\left(m_{2}-m_{1}\right) / A \sqrt{t}$,

where:

$$
\begin{aligned}
& C \text { - water absorption coefficient }\left[\mathrm{kg} \cdot \mathrm{m}^{-2} \cdot \mathrm{min}^{-0.5]}\right. \\
& m_{1} \text { - mass of a specimen after } 10 \text { minutes }[\mathrm{kg}] \\
& m_{2} \text { - mass of a specimen after } 90 \text { minutes }[\mathrm{kg}] \\
& A \text { - water contact surface }\left[\mathrm{m}^{2}\right] \\
& t \text { - time [min.] }
\end{aligned}
$$

The water absorption coefficient expresses the rate of capillarity action in a certain period of time. It is mathematically defined as a tangent to the capillary water content function $[45,46]$.

\section{Achieved results}

The compressive strength over time of the tested mortars is presented in Fig. 1. The strength of all the tested mortars grew over time. The early strength of SM, after two and seven days of curing, is significantly lower in comparison to the modified mortars. After 28 days of curing, the strength of mortars ranges from 36.5 MPa (MM 0.6) to 47.4 (MM 0.4). The highest strength is achieved after 56 days of curing by SM, and it is equal to $50.4 \mathrm{MPa}$. In the case of the modified mortars, the change in compressive strength between the $28^{\text {th }}$ and $56^{\text {th }}$ day of curing is negligible (less than $1 \%$ ). In Fig. 2, the flexural strength over time of the mortars is presented. Again, the early strength of SM is significantly lower in comparison to the modified mortars. After 28 days of curing, the strength of the mortars ranges from 5.0 $\mathrm{MPa}(\mathrm{MM} \mathrm{0.6)}$ to $6.8 \mathrm{MPa}$ (SM and MM 0.4). Using the standard requirements for mortars used in ordinary brickwork described in PN-B-10104:2005 [47] and PN-EN 998-1:2004 [48], all the tested mortars achieved the highest possible strength class of M20.

After the 28th day of curing, all the mortars gained strength, reaching values from 7.0 $\mathrm{MPa}$ (MM 0.5) to $7.6 \mathrm{MPa}$ (MM 0.4) after 56 days of curing. The results of the absorptivity test are presented in Fig. 3. SM was characterized by an absorptivity equal to $7.5 \%$. The absorptivity of the cement mortars, according to PN-EN 998-1:2004, should be up to $10 \%$. Thus, SM fulfilled this requirement. The absorptivity of the modified mortars ranges from

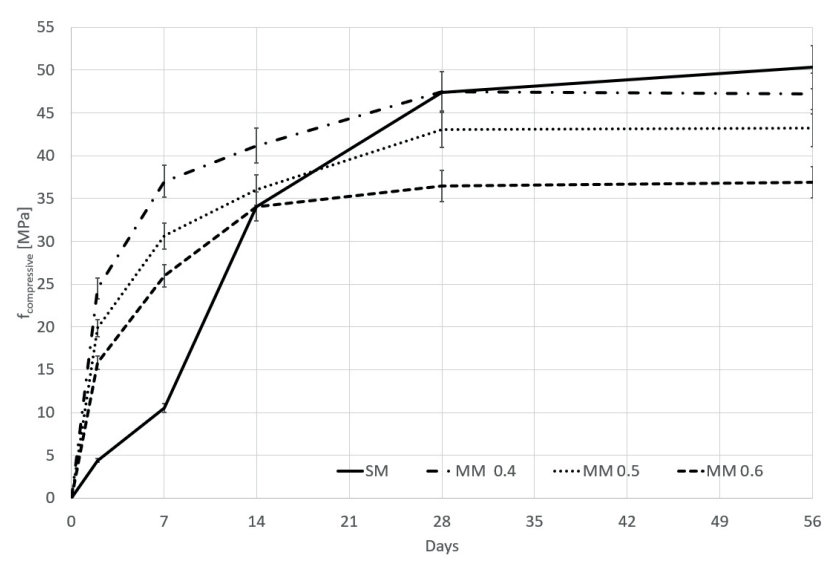

Fig. 1 Compressive strength over time

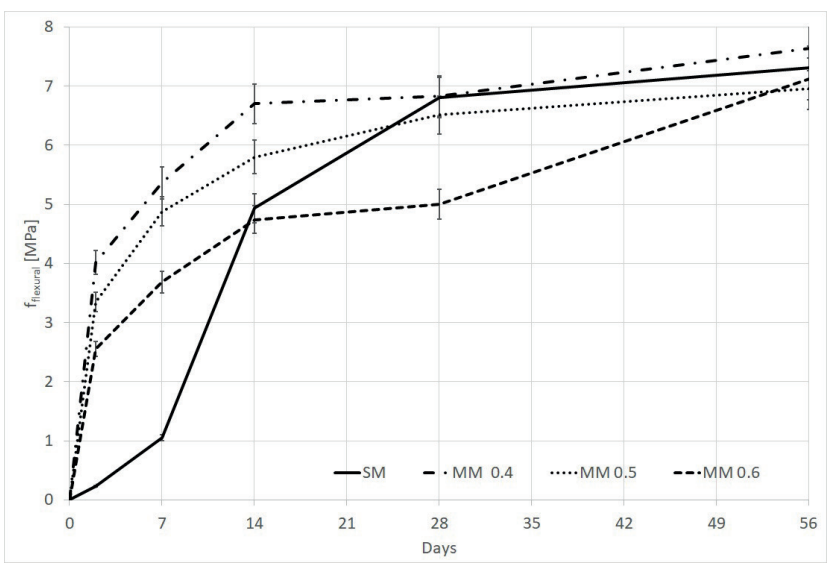

Fig. 2 Flexural strength over time

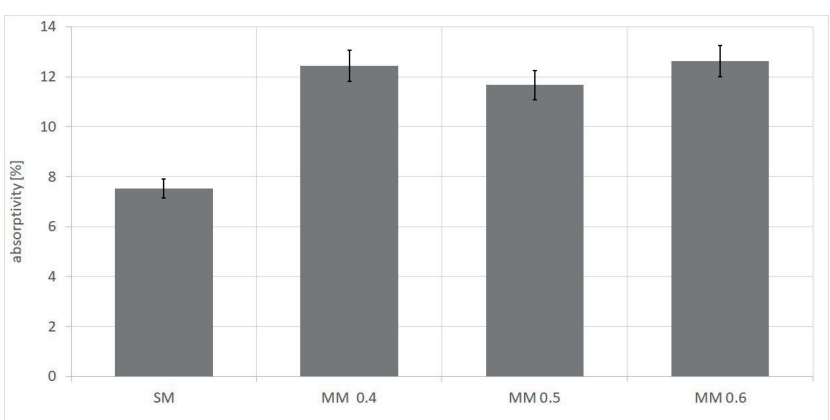

Fig. 3 Absorptivity of the tested mortars after 28 days of curing 
$11.7 \%$ to $12.6 \%$. The differences between the absorptivity of the modified mortars are too small to differentiate. They all range in terms of the accuracy of the conducted measurement.

All MMs are made with a small amount of lime, and a limit of absorptivity of $12 \%$ for cement-lime mortars can thus be used in this instance (PN-EN 998-1:2004). Nevertheless, all the MMs did not fulfill this requirement.

The values for the calculated water absorption coefficient are presented in Fig. 4. SM is characterized by a $C$ equal to $0.64 \mathrm{~kg} \cdot \mathrm{m}^{-2} \cdot \mathrm{min}^{-0.5}$. The modified mortars are characterized by $C$ values equal to $0.75 \pm 0.05 \mathrm{~kg} \cdot \mathrm{m}^{-2} \cdot \mathrm{min}^{-0.5}$ and are difficult to differentiate, taking into account the accuracy of the conducted measurements. There are three classes (W0, W1, and W2) associated with the water absorption coefficient (PN-EN 998-1:2004). Class W0 has no requirements in terms of the water absorption coefficient value. Class $\mathrm{W} 1$ and $\mathrm{W} 2$ have a $C$ limit equal to $0.40 \mathrm{~kg} \cdot \mathrm{m}^{-2} \cdot \mathrm{min}^{-0.5}$ and $0.20 \mathrm{~kg} \cdot \mathrm{m}^{-2} \cdot \mathrm{min}^{-0.5}$, respectively. All the tested mortars should be classified as W0. The achieved $C$ values closely mirror the absorptivity results (see Fig. 3).

In Figs. 5 and 6, the loss of mass of the specimens subjected to freeze-thaw cycles, conducted using water and a $3 \% \mathrm{NaCl}$ solution, respectively, is presented. During the cycles conducted in water only, the specimens of MM 0.6 were ultimately destroyed after 50 cycles. Examples of ultimately destroyed specimens, which are impossible to test after freeze-thaw cycles, are presented in Fig. 7.

In the case of specimens tested in a $3 \% \mathrm{NaCl}$ solution, all the specimens of the modified mortars were ultimately destroyed. The specimens of MM 0.5 and MM 0.6 were destroyed after 26 cycles. The specimens of MM 0.4 were destroyed after 38 cycles. The specimens made of SM maintained their structural integrity, but after 50 cycles, they lost $27.8 \%$ of their original mass. In both cases (cycles conducted in water and in a $3 \% \mathrm{NaCl}$ solution), the MM 0.6 was the least resistant to freeze-thaw cycles. The freeze-thaw cycles conducted using water were significantly less destructive for all tested mortars. The number of cycles should be much larger to follow the process of destroying SM, MM 0.4, and MM 05. The standard for ordinary mortars (PN-EN 998-1:2004) require that mortars with the strength class, M20, are characterized by a loss of mass of up to $1 \%$ after 25 freeze-thaw cycles (conducted in fresh water). All the tested mortars fulfil this requirement. There are no requirements concerning the loss of mass after freeze-thaw cycles conducted using

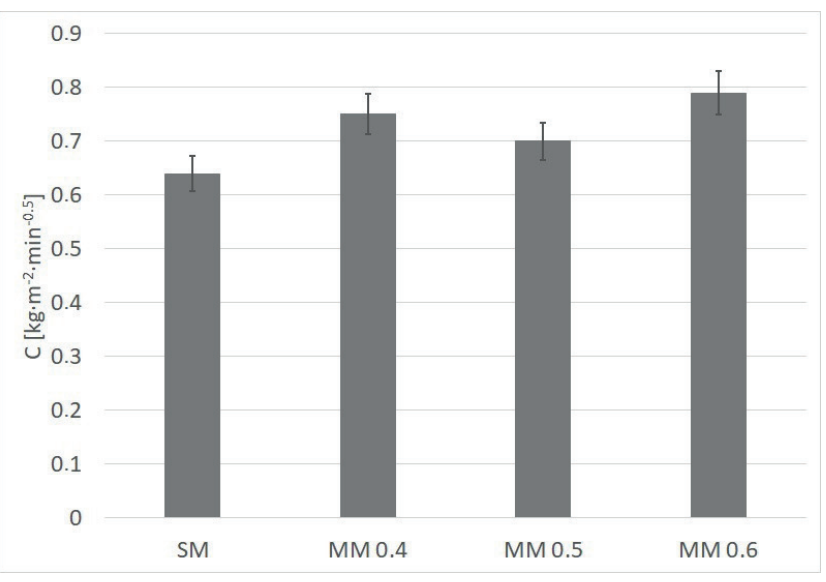

Fig. 4 Water absorption coefficient

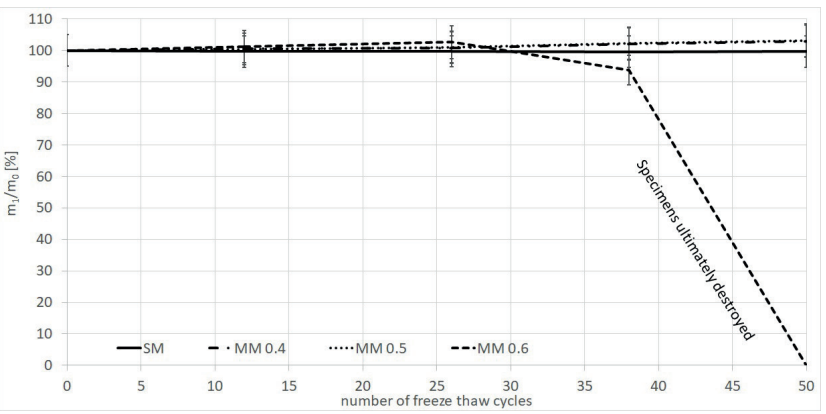

Fig. 5 Loss of mass after freeze-thaw cycles conducted using water

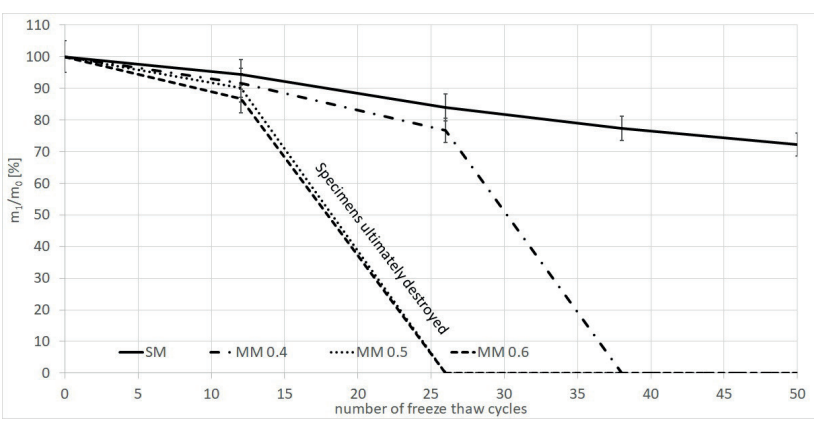

Fig. 6 Loss of mass after freeze-thaw cycles conducted using a $3 \%$ $\mathrm{NaCl}$ solution

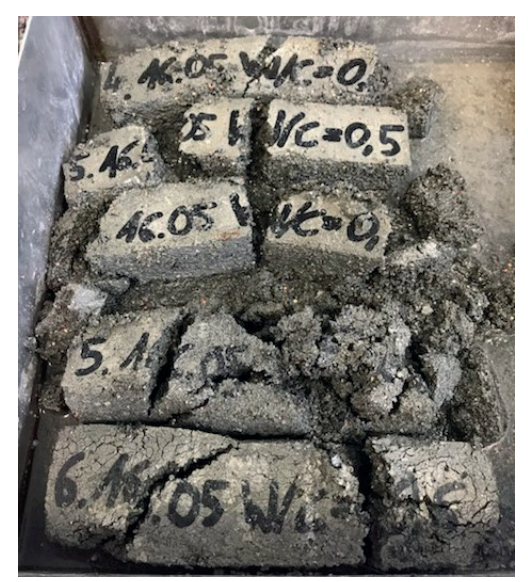

Fig. 7 Specimens of MM 0.5 after 26 freeze-thaw cycles using a $3 \%$ $\mathrm{NaCl}$ solution 


\section{a $3 \% \mathrm{NaCl}$ solution.}

\section{Discussion}

The conducted research program proved that it is possible to create mortars with $50 \%$ of sand substituted with fly ash and slag. The mechanical characteristics of the modified mortars, MM 0.4 and MM 0.5, are satisfactory. What is more, after 28 and 56 days of curing, they are characterized by similar properties to SM. Both mortars are characterized by a larger compressive and flexural strength after 7 and 14 days of curing in comparison to SM. This is an advantage in the case of bricklaying and other finishing works during the construction process. The MM 0.6 is characterized by a significantly lower strength and durability in comparison to the other two modified mortars, and it should therefore be removed from further tests.

The results of durability-associated properties (absorptivity, water absorption coefficient, and loss of mass after freeze-thaw cycles) show large differences between SM and the modified mortars. Therefore, the modified mortars should be considered only for ap-plications where they are not exposed to elements. Fortunately, there are plenty of such applications in the construction industry. It is worth pointing out that SM achieved the highest compressive strength after 56 days of curing, the lowest absorptivity after 28 days of curing, the lowest water absorption coefficient, and the lowest loss of mass after freeze-thaw cycles conducted using a $3 \% \mathrm{NaCl}$ solution. It is pretty clear that the SM is the best solution when no admixtures are used, or internal curing is employed. The consistency of fresh mortar was achieved through the volume of paste used, resulting in a higher cement consumption in comparison to SM. The next research program should be focused on creating MM using superplasticizers and stabilizers. The utilization of both types of admixtures should help to reduce binder consumption and, at the same time, maintain a good workability [49]. Due to the porous structure of slag, the phenomenon of internal curing [50] should be employed too. Pre-saturating fine slag particles would help both to achieve the desired consistency and significantly improve the strength characteristics of MM through internal curing. It is also possible to use water with a diluted superplasticizer for pre-saturating in order to increase the efficiency of the internal curing process [51]. One can also predict the strength and durability characteristics will also be improved through the denser internal structure of the mortar and better binder hydration.
The modified mortars in question only partially fulfilled the standard requirements for ordinary mortars. The key issues are associated with the absorptivity, which is on the edge of the standard threshold, and the high water absorption coefficient values. It is very likely that both issues can be successfully addressed by using a superplasticizer and internal curing process. The internal structure of MMs should be much denser and water-tight as a result of these treatments.

Modern mortars are becoming more and more complex. Using waste materials for their production (especially replacing significant amounts of sand) is a challenge requiring a new technological approach and attitude change in the construction industry [52]. Modern mortar is as complex as modern concrete and should be treated in the same technological, design, and production regime.

\section{Conclusions}

The conducted research program allows the following conclusions to be drawn:

- the modified mortars are characterized by satisfactory results in terms of both compressive and flexural strengths, enabling their application in civil engineering,

- the modified mortars are characterized by a high absorptivity (with an average of $12.15 \%$ ), which is almost twice as high as the absorptivity of the SM,

- the water absorption coefficient of the modified mortars is higher in comparison to the SM,

- the resistance of MM 0.4 and MM 0.5 to freezethaw cycles conducted using water is the same as the resistance of SM,

- the resistance to freeze-thaw cycles conducted using a $3 \% \mathrm{NaCl}$ solution of the modified mortars is almost non-existent,

- the low resistance to freeze-thaw cycles and high absorptivity of the modified mortars prevent them from being applied in places exposed to elements,

- MM 0.6 is characterized by the worst strength and durability properties out of all the tested mortars and should therefore not be subjected to further testing,

- the mortars were prepared in a traditional way (the consistency was regulated by the amount of cement-lime paste) and thus had a reasonably high binder consumption,

- future tests should cover modified mortars created with superplasticizers. 


\section{Acknowledgement}

The research program was executed as a part of the Master Thesis of Paweł Kończalski under the supervision of Prof. Jacek Katzer at the Faculty of Geoengineering, the

\section{References}

[1] Rai, A., Joshi, Y. P. "Applications and Properties of Fibre Reinforced Concrete", International Journal of Engineering Research and Application, 4(5), pp. 123-131, 2014.

[2] Afroughsabet, V., Biolzi, L., Ozbakkaloglu, T. "High-performance fiber-reinforced concrete: a review", Journal of Materials Science, 51, pp. 6517-6551, 2016.

https://doi.org/10.1007/s10853-016-9917-4

[3] Lehner, P., Konečný, P., Ponikiewski, T. "Comparison of Material Properties of SCC Concrete with Steel Fibres Related to Ingress of Chlorides", Crystals, 10(3), Article No 220, 2020.

https://doi.org/10.3390/cryst10030220

[4] Okamara, H., Ouchi, M. "Self-Compacting Concrete", Journal of Advanced Concrete Technology, 1(1), pp. 5-15, 2003.

https://doi.org/10.3151/jact.1.5

[5] Cuenca, E., Serna, P. "Autogenous Self-Healing Capacity of Early-Age Ultra-High-Performance Fiber-Reinforced Concrete", Sustainability, 13(6), Article No. 3061, 2021. https://doi.org/10.3390/su13063061

[6] Abbas, S., Nehdi, M. L., Saleem, M. A. "Ultra-High Performance Concrete: Mechanical Performance, Durability, Sustainability and Implementation Challenges", International Journal of Concrete Structures and Materials, 10, pp. 271-295, 2016.

https://doi.org/10.1007/s40069-016-0157-4

[7] Buswell, R. A., Leal de Silva, W. R., Jones, S. Z., Dirrenberger, J. "3D printing using concrete extrusion: A roadmap for research", Cement and Concrete Research, 112, pp 37-49, 2018. https://doi.org/10.1016/j.cemconres.2018.05.006

[8] Gosselin, C., Duballet, R., Roux, P., Gaudillière, N., Dirrenberger, J., Morel, P. "Large-scale 3D printing of ultra-high performance concrete - a new processing route for architects and builders", Materials and Design, 100, pp. 102-109, 2016. https://doi.org/10.1016/j.matdes.2016.03.097

[9] Mehta, P. K. "Global Concrete Industry Sustainability", ACI Concrete International, 31(2), pp. 45-48, 2009.

[10] Penttala, V. "Concrete and Sustainable Development", ACI Materials Journal, 94(5), pp. 409-416, 1997. https://doi.org/10.14359/325

[11] UNEP "Sand, rarer than one thinks", UNEP Global Environmental Alert Service (GEAS), Sioux Falls, SD, USA, 2014.

[12] Malešev, M., Radonjanin, V., Marinković, S. "Recycled Concrete as Aggregate for Structural Concrete Production", Sustainability, 2(5), pp. 1204-1225, 2010. https://doi.org/10.3390/su2051204

[13] Akhtar, A., Sarmah, A. K. "Construction and demolition waste generation and properties of recycled aggregate concrete: A global perspective", Journal of Cleaner Production, 186, pp. 262-281, 2018. https://doi.org/10.1016/j.jclepro.2018.03.085
University of Warmia and Mazury in Olsztyn, Poland. The authors thank Prof. Marek Ciak for his help in the preparation of the research program.

[14] Mohajerani, A., Vajna, J., Cheung, T. H. H., Kurmus, H., Arulrajah, A., Horpibulsuk, S. "Practical recycling applications of crushed waste glass in construction materials: A review", Construction and Building Materials, 156, pp. 443-467, 2017.

https://doi.org/10.1016/j.conbuildmat.2017.09.005

[15] Ismail, Z. Z., AL-Hashmi, E. A. "Recycling of waste glass as a partial replacement for fine aggregate in concrete", Waste Management, 29(2), pp. 655-659, 2009. https://doi.org/10.1016/j.wasman.2008.08.012

[16] de Brito, J., Pereira, A. S., Correia, J. R. "Mechanical behaviour of non-structural concrete made with recycled ceramic aggregates", Cement and Concrete Composites, 27(4), pp. 429-433, 2005. https://doi.org/10.1016/j.cemconcomp.2004.07.005

[17] Evangelista, L., de Brito, J. "Mechanical behaviour of concrete made with fine recycled concrete aggregates", Cement and Concrete Composites, 29(5), pp. 397-401, 2007.

https://doi.org/10.1016/j.cemconcomp.2006.12.004

[18] Domski, J., Katzer, J. "Comprehensive approach to evaluation of mechanical properties of waste aggregate concrete reinforced by steel fiber", Structural Concrete, 21(1), pp. 428-436, 2020. https://doi.org/10.1002/suco.201800271

[19] Dash, M. K., Patro, S. K., Rath, A. K. "Sustainable use of industrial-waste as partial replacement of fine aggregate for preparation of concrete - A review", International Journal of Sustainable Built Environment, 5(2), pp. 484-516, 2016. https://doi.org/10.1016/j.ijsbe.2016.04.006

[20] Pilegis, M., Gardner, D., Lark, R. "An Investigation into the Use of Manufactured Sand as a 100\% Replacement for Fine Aggregate in Concrete", Materials, 9(6), Article No 440, 2016. https://doi.org/10.3390/ma9060440

[21] Singh, Y., Vyas, A. K., Syed Ahmed Kabeer, K. I. "Compressive Strength Evaluation of Mortars Containing ISF Slag and Marble Powder", Materials Today: Proceedings, 4(9), pp. 9635-9639, 2017. https://doi.org/10.1016/j.matpr.2017.06.239

[22] Halbiniak, J., Katzer, J., Major, M., Major, I. "A Proposition of an In Situ Production of a Blended Cement", Materials, 13(10), Article No. 2289, 2020. https://doi.org/10.3390/ma13102289

[23] Golaszewski, J., Kostrzanowska-Siedlarz, A., Ponikiewski, T., Miera, P. "Influence of Multicomponent and Pozzolanic Cements Containing Calcareous Fly Ash and Other Mineral Admixtures on Properties of Fresh Cement Mixtures", IOP Conference Series: Materials Science and Engineering, 471, Article No 112024, 2019. https://doi.org/10.1088/1757-899X/471/11/112024

[24] Javali, S., Chandrashekar, A. R., Naganna, S. R., Manu, D. S., Hiremath, P., Preethi, H. G., Kumar N. V. "Eco-concrete for sustainability: utilizing aluminium dross and iron slag as partial replacement materials", Clean Technologies and Environmental Policy, 19, pp. 2291-2304, 2017.

https://doi.org/10.1007/s10098-017-1419-9 
[25] Bhoi, A. M., Patil, Y. D., Patil, H. S., Kadam, M. P. "Feasibility Assessment of Incorporating Copper Slag as a Sand Substitute to Attain Sustainable Production Perspective in Concrete", Advances in Materials Science and Engineering, 2018, Article ID 6502890, 2018. https://doi.org/10.1155/2018/6502890

[26] Zygmunt, J., Prokopski, G. "Properties of cement concretes modified by mechanically activated siliceous fly ash", Roads and Bridges - Drogi i Mosty, 8(2), pp. 63-85, 2009.

[27] Nowak-Michta, A. "Compressive strength of siliceous fly ash concretes", Technical Transactions - Czasopismo Techniczne, 109(2), pp. 77-98, 2012.

https://doi.org/10.4467/2353737XCT.14.110.1887

[28] Langier, B., Halbiniak, J., Adamus, J. "Investigation of frost resistance of fly ash concrete with air-entraining admixture", Journal of Environmental Protection and Ecology, 16(3), pp. 1160-1167, 2015.

[29] PKN "PN-EN 206+A1:2016-12 Concrete. Specification, Performance, Production and Conformity", Polski Komitet Normalizacyjny, Warsaw, Poland, 2017.

[30] Harasymiuk, J., Rudziński, A. "Old Dumped Fly Ash as a Sand Replacement in Cement Composites", Buildings, 10(4), Article No 67, 2020.

https://doi.org/10.3390/buildings10040067

[31] Atzeni, C., Massidda, L., Sanna, U. "Use of granulated slag from lead and zinc processing in concrete technology", Cement and Concrete Research, 26(9), pp. 1381-1388, 1996. https://doi.org/10.1016/0008-8846(96)00121-4

[32] Tripathi, B., Chaudhary, S. "Performance based evaluation of ISF slag as a substitute of natural sand in concrete", Journal of Cleaner Production, 112(1), pp. 672-683, 2016.

https://doi.org/10.1016/j.jclepro.2015.07.120

[33] Yiğiter, H., Yazıcı, H., Aydin, S. "Effects of cement type, water/ cement ratio and cement content on sea water resistance of concrete", Building and Environment, 42(4), pp. 1770-1776, 2007. https://doi.org/10.1016/j.buildenv.2006.01.008

[34] Szweda, Z., Ponikiewski, T., Katzer, J. "A study on replacement of sand by granulated ISP slag in SCC as a factor formatting its durability against chloride ions", Journal of Cleaner Production, 156, pp. 569-576, 2017. https://doi.org/10.1016/j.jclepro.2017.04.072

[35] CEN "EN 197-1 Cement - Part 1: Composition, Specifications and Conformity Criteria for Common Cements", European Committee for Standardization, Brussels, Belgium, 2000.

[36] Katzer, J. "Impact and dynamic resistance of SFRCC modified by varied superplasticizers", Archives of Civil and Mechanical Engineering, 11(1), pp. 103-113, 2011. https://doi.org/10.1016/S1644-9665(12)60177-0

[37] Katzer, J. "Median diameter as a grading characteristic for fine aggregate cement composite designing", Construction and Building Materials, 35, pp. 884-887, 2012. https://doi.org/10.1016/j.conbuildmat.2012.04.050

[38] Kett, I. "Engineered Concrete, Mix Design and Test Methods", 2nd ed., CRC Press, Boca Raton, FL, USA, 2009. https://doi.org/10.1201/9781420091175
[39] PKN "PN-EN 196-2:2013-11 Cement test methods - Part 2: Chemical analysis of cement", Polski Komitet Normalizacyjny, Warsaw, Poland, 2013.

[40] Katzer, J., Szatkiewicz, T. "Effect of 3D Printed Spatial Reinforcement on Flexural Characteristics of Conventional Mortar", Materials, 13(14), Article No 3133, 2020. https://doi.org/10.3390/ma13143133

[41] PKN "PN-EN 1015-3:2000 Mortar test methods for masonry Determining the consistency of fresh mortar (using a spreader table)", Polski Komitet Normalizacyjny, Warsaw, Poland, 2000.

[42] PKN "PN-EN 1015-6:2000 Test methods for mortars for masonry - Determination of bulk density of fresh mortar", Polski Komitet Normalizacyjny, Warsaw, Poland, 2000.

[43] PKN "196-1:2016-07 Cement test methods - Part 1: Determination of strength", Polski Komitet Normalizacyjny, Warsaw, Poland, 2016.

[44] PKN "PN-EN 1015-18:2003 Test methods for mortars for masonry - Part 18: Determination of the coefficient of water absorption due to capillary rise of the hardened mortar", Polski Komitet Normalizacyjny, Warsaw, Poland, 2003.

[45] Sicakova, A., Draganovska, M., Kovac, M. "Water Absorption Coefficient as a Performance Characteristic of Building Mixes Containing Fine Particles of Selected Recycled Materials", Procedia Engineering, 180, pp. 1256-1265, 2017. https://doi.org/10.1016/j.proeng.2017.04.287

[46] Thamboo, J. A., Bandara, A. A., Jayarathne, R. N. "Fresh and hardened properties of various cement and cement-lime masonry mortars", presented at 10th International Masonry Conference, Milan, Italy, July, 9-11, 2018.

[47] PKN "PN-B-10104:2005 Requirements for general purpose masonry mortars - Mortars with a specific material composition, manufactured on the construction site", Polski Komitet Normalizacyjny, Warsaw, Poland, 2005.

[48] PKN "PN-EN 998-1:2004 Requirements for mortars for masonry Part 1: Plastering mortar", Polski Komitet Normalizacyjny, Warsaw, Poland, 2004.

[49] Gołaszewski, J., Ponikiewski, T., Kostrzanowska-Siedlarz, A., Miera, P. "The Influence of Calcareous Fly Ash on the Effectiveness of Plasticizers and Superplasticizers", Materials, 13(10), Article No 2245, 2020. https://doi.org/10.3390/ma13102245

[50] Jensen, O. M., Lura, P. "Techniques and materials for internal water curing of concrete", Materials and Structures/Materiaux et Constructions, 39, pp. 817-825, 2006. https://doi.org/10.1617/s11527-006-9136-6

[51] Wyrzykowski, M., Lura, P., Pesavento, F., Gawin, D. "Modeling of internal curing in maturing mortar", Cement and Concrete Research, 41(12), pp. 1349-1356, 2011.

https://doi.org/10.1016/j.cemconres.2011.04.013

[52] Seitl, S., Bílek, V., Keršner, Z., Veselý, J. "Cement based composites for thin building elements: Fracture and fatigue parameters", Procedia Engineering, 2(1), pp. 911-916, 2010. https://doi.org/10.1016/j.proeng.2010.03.098 